\title{
KARAKTERISTIK YOGHURT KERING YANG DIPERKAYA DIFRUCTOSE ANHYDRIDE III DARI UMBI DAHLIA SEBAGAI MINUMAN FUNGSIONAL
}

\author{
The Characteristics of Dried Yogurt Enriched by Difructose Anhydride III \\ from Dahlia Tubers as Functional Drink
}

\author{
Ainia Herminiati', Rimbawan², Budi Setiawan², Dewi Apri Astuti ${ }^{3}$, Linar Zalinar Udin ${ }^{4}$ \\ ${ }^{1}$ Pusat Pengembangan Teknologi Tepat Guna, Lembaga Ilmu Pengetahuan Indonesia, \\ Jl. Aipda K.S. Tubun No. 5 Subang 41213 \\ ${ }^{2}$ Departemen Gizi Masyarakat, Fakultas Ekologi Manusia, Institut Pertanian Bogor, \\ Jl. Lingkar Akademik, Kampus IPB Darmaga Bogor 16680 \\ ${ }^{3}$ Departemen Ilmu Nutrisi dan Teknologi Pakan, Fakultas Peternakan, \\ Institut Pertanian Bogor, Jl. Agatis Kampus IPB Darmaga Bogor 16680 \\ ${ }^{4}$ Pusat Penelitian Kimia, Lembaga Ilmu Pengetahuan Indonesia, \\ Jl. Cisitu-Sangkuriang, Bandung 40135 \\ Email: herminiati@yahoo.com
}

\begin{abstract}
ABSTRAK
Yoghurt kering merupakan salah satu inovasi pengembangan produk yoghurt. Yoghurt kering dapat meningkatkan daya simpan yoghurt serta lebih praktis karena mengurangi volume sehingga lebih memudahkan dalam proses distribusi. Pengayaan yoghurt kering dengan Difructose Anhydride III sebagai pangan fungsional yang berperan dalam meningkatkan penyerapan kalsium bermanfaat sebagai pencegahan terhadap osteoporosis. Tujuan dari penelitian ini adalah untuk menganalisis karakteristik yoghurt kering yang diperkaya dengan DFA III dari umbi dahlia dan umbi chicory sebagai minuman fungsional terhadap sifat kimia, fisik, mikrobiologi, dan organoleptik. Metode penelitian meliputi: (1) proses pembuatan yoghurt kering tanpa pengayaan (Y), diperkaya dengan DFA III dari umbi dahlia (YD), dan diperkaya dengan DFA III komersial dari umbi chicory (YC), (2) pengujian sifat kimia, fisik, mikrobiologi, dan organoleptik. Hasil penelitian menunjukkan bahwa tingkat kemurnian DFA III dari umbi dahlia 96,0\% dan DFA III komersial dari umbi chicory $99,9 \%$. Hasil terbaik diperoleh dari yoghurt kering yang diperkaya dengan DFA III dari umbi dahlia (YD) menghasilkan rendemen 17,83 $\pm 0,36 \%$ lebih tinggi secara nyata dibandingkan dengan tanpa pengayaan (Y) $14,90 \pm 1,27 \%$ dan pengayaan dengan DFA III dari umbi chicory $(\mathrm{YC}) 14,71 \pm 1,69 \%(\mathrm{p}<0,05)$. Produk YD mengandung

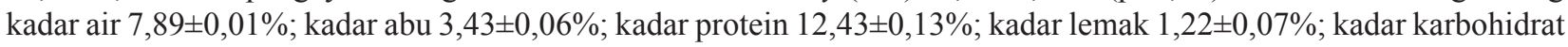

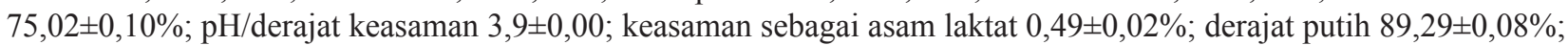
dan viabilitas bakteri asam laktat 1,20x107cfu.g-1. Pengujian organoleptik menggunakan 40 panelis semi terlatih, dengan hasil penilaian untuk aroma dan warna menunjukkan kriteria suka, untuk tekstur dan rasa menunjukkan kriteria agak suka. Yoghurt kering yang diperkaya dengan DFA III dari umbi dahlia yang bersifat prebiotik dapat meningkatkan viabilitas bakteri asam laktat sebagai probiotik yang menunjukkan bahwa produk tersebut dapat digolongkan sebagai produk sinbiotik dan dapat digunakan sebagai minuman fungsional untuk meningkatkan penyerapan kalsium sebagai pencegahan terhadap osteoporosis.
\end{abstract}

Kata kunci: Difructose Anhydride III, karakteristik, pengayaan, yoghurt kering

\begin{abstract}
Dried yogurt is one of yogurt product development innovations. Beside increases the shelf life, dried yogurt is also more practical because it reduces the volume to the easier distribution process. Dried yogurt enriched by Difructose Anhydride III as functional food in increasing calcium absorption is useful as osteoporosis prevention. The purpose of this study was to analyze the characteristics of dried yogurt enriched by DFA III from dahlia and chicory tubers as functional drink on physicochemical, microbiology, and organoleptic properties. The research stages include: (1) The production of dried yogurt without enrichment (Y), with DFA III enrichment from dahlia tubers (YD), and with DFA
\end{abstract}


III commercial enrichment from chicory tubers (YC), (2) The test for physicochemical, microbiology, and organoleptic properties. The results showed that the purity level of DFA III from dahlia tubers was $96.0 \%$ and commercial DFA III from chicory tubers was $99.9 \%$. The best results were obtained from the dried yogurt enriched by DFA III from dahlia tubers (YD) which produced yield of $17.83 \pm 0.36 \%$. It was significantly higher than dried yogurt without enrichment (Y) which produced yield of $14.90 \pm 1.27 \%$ and dried yogurt enriched by DFA III from chicory tubers (YC) which produced yield of $14.71 \pm 1.69 \%(\mathrm{p}<0.05)$. YD product had moisture content of $7.89 \pm 0.01 \%$; ash content of $3.43 \pm 0.06 \%$; protein content of $12.43 \pm 0.13 \%$; fat content of $1.22 \pm 0.07 \%$; carbohydrate content of $75.02 \pm 0.10 \%$; pH/acidity of $3.9 \pm 0.00$; acidity as lactic acid of $0.49 \pm 0.02 \%$; whiteness degree of $89.29 \pm 0.08 \%$; and lactic acid bacteria viability of $1.20 \times 10^{7}$ cfu.g-1. Organoleptic test was conducted by 40 semi-trained panelists. The results showed that for flavour and color levels got like preference, while for texture and taste level got medium-like preference. Dried yogurt enriched by DFA III from dahlia tubers could improve the viability of lactic acid bacteria as probiotic. It means that the dried yogurt could be classified as synbiotik products and used as a functional drink to increase calcium absorption as osteoporosis prevention.

Keywords: Difructose Anhydride III, characteristics, enrichment, dried yogurt

\section{PENDAHULUAN}

Difructose Anhydride III merupakan senyawa disakarida siklik dan termasuk dalam kategori pangan fungsional, dapat dihasilkan melalui proses enzimatis dari umbi chicory dengan menggunakan enzim fructosyltransferase Arthrobacter sp. H65-7 (Kikuchi dkk., 2009). Pudjiraharti dan Asano (2012) menggunakan enzim inulinfruktotransferase yang diisolasi dari Nonomuraea sp. ID06-A0189 untuk proses pembuatan DFA III dari umbi dahlia. DFA III telah terbukti dapat meningkatkan penyerapan kalsium pada usus tikus, sapi dan manusia yang berperan sebagai carrier/transporter, reseptor, kofaktor, pentrigger pembuka signal channel kalsium, dan memberi pengaruh asam pada usus besar (Suzuki dkk., 1998; 2004; Mitamura dkk., 2002; Shigematsu dkk., 2004; Minamida dkk., 2006; Sato dkk., 2007). Berdasarkan hal tersebut, DFA III sebagai prebiotik dapat dikonsumsi dengan cara ditambahkan pada produk pangan fungsional yang berperan dalam meningkatkan penyerapan kalsium dan bermanfaat sebagai pencegahan osteoporosis.

Yoghurt mengandung kadar kalsium relatif tinggi 145 mg. $100 \mathrm{~g}^{-1}$ (Tamime dan Robinson, 2007). Menurut Mazahreh dan Ershidat (2009) bahwa produk yoghurt mengandung protein $4,30 \%$; riboflavin $0,21 \%$; kalsium $0,16 \%$; dan fosfor $0,13 \%$. Salah satu pangan fungsional yang populer di kalangan masyarakat dan dikembangkan oleh industri pangan adalah susu fermentasi dalam bentuk yoghurt (Jenie, 2003). Donkor dkk. (2007) menjelaskan bahwa yoghurt yang mengandung probiotik dengan ditambahkan prebiotik dapat meningkatkan konsentrasi asam asetat dan asam laktat, keberadaan asam laktat dan short chain fatty acid (SCFA) di dalam usus besar mampu meningkatkan penyerapan kalsium.

Kadar kalsium yang relatif tinggi dari yoghurt dapat diberikan sebagai konsumsi harian pada wanita pre-menopause dan pasca-menopause untuk memelihara kesehatan tulangnya dan mencegah terjadinya osteoporosis (Hardcastle dkk., 2011). Menurut Jenie (2003) keunggulan yoghurt selain mengandung kalsium yang tinggi, apabila dikonsumsi secara teratur dapat menyeimbangkan mikroflora usus, dimana bakteri-bakteri yang merugikan dapat ditekan jumlahnya dan usus akan didominasi oleh bakteri yang menguntungkan. Saint-Eve dkk. (2006) mengemukakan bahwa yoghurt adalah salah satu produk susu yang paling umum dikonsumsi di seluruh dunia, dan memiliki atribut sensori yang berpengaruh besar terhadap penerimaan konsumen. Hal tersebut menunjukkan bahwa yoghurt dapat diperkaya dengan DFA III dengan tujuan meningkatkan penyerapan kalsium bagi yang mengkonsumsinya.

Pengembangan produk pangan fungsional dari yoghurt yang diperkaya dengan DFA III dapat dibuat dalam bentuk kering. Menurut Eddy (1999) kelebihan yoghurt kering adalah dapat disimpan dalam bentuk yang stabil dan siap untuk digunakan, juga dapat memperpanjang masa simpan yoghurt. Penyajian yoghurt ini dengan cara melarutkan 10 gram yoghurt kering ke dalam $100 \mathrm{ml}$ air. Tujuan penelitian ini untuk menganalisis karakteristik yoghurt kering yang diperkaya dengan DFA III dari umbi dahlia dan umbi chicory terhadap sifat kimia, fisik, mikrobiologi, dan organoleptik.

\section{METODE PENELITIAN}

\section{Bahan dan Alat yang Digunakan}

Bahan yang digunakan meliputi: yoghurt segar diperoleh dari Laboratorium Teknologi Hasil Peternakan Fakultas Peternakan IPB; DFA III dari umbi dahlia (Dahlia pinnata) diperoleh dari Pusat Penelitian Kimia LIPI; DFA III dari umbi chicory (Chicoryum intybus L.) diperoleh dari Nippon Beet Sugar Mfg. Co. Ltd. Obihiro Hokkaido Jepang; pati jagung, susu skim, sukrosa, asam sitrat dan gum arab diperoleh dari 
toko bahan kimia di Bogor. Peralatan yang digunakan adalah spray dryer (Buchi 190, Swedia), homogenizer (Armfield L4R, Inggris), peralatan gelas untuk analisis kimia, $\mathrm{pH}$ meter, peralatan untuk pengujian organoleptik, dan Scanning Electron Microscopy (JEOL JSM 6510 LA, Jepang).

\section{Pengayaan DFA III pada Yoghurt (Modifikasi Eddy, 1999; Lestari, 2011)}

Perlakuan yang dilakukan meliputi: yoghurt kering tanpa pengayaan (Y), yoghurt kering diperkaya dengan DFA III dari umbi dahlia (YD), dan yoghurt kering diperkaya dengan DFA III dari umbi chicory (YC). Rancangan percobaan menggunakan metode eksperimental dengan pola Rancangan Acak Lengkap (RAL) dengan tiga taraf dan dilakukan tiga kali ulangan.

Proses pembuatan yoghurt kering dilakukan dengan cara yoghurt segar ditambahkan pati jagung, DFA III, susu skim, sukrosa, asam sitrat, dan gum arab. Selanjutnya dilakukan pencampuran menggunakan homogenizer $1000 \mathrm{rpm}$ selama 10 menit sampai homogen. Tahap berikutnya dilakukan proses pengeringan menggunakan spray dryer dengan suhu inlet $120^{\circ} \mathrm{C}$ dan outlet $80^{\circ} \mathrm{C}$. Yoghurt kering tanpa pengayaan dibuat dengan bahan yang sama tetapi tanpa penambahan DFA III. Pada Tabel 1 dapat dilihat formulasi yoghurt kering dengan 3 perlakuan.

Tabel 1. Formulasi yoghurt kering dengan 3 perlakuan

\begin{tabular}{lcccc}
\hline \multicolumn{1}{c}{ Komposisi } & $\begin{array}{c}\text { Tanpa } \\
\text { pengayaan } \\
(\mathrm{g})\end{array}$ & $\begin{array}{c}\text { Diperkaya } \\
\text { DFA III umbi } \\
\text { dahlia }(\mathrm{g})\end{array}$ & $\begin{array}{c}\text { Diperkaya } \\
\text { DFA III umbi } \\
\text { chicory }(\mathrm{g})\end{array}$ \\
\hline Yoghurt segar & 500 & 500 & 500 \\
Pati jagung & $10,0 \%$ & 50 & 50 & 50 \\
DFA III & $3,0 \%$ & 0 & 15 & 15 \\
Susu skim & $1,9 \%$ & 9,5 & 9,5 & 9,5 \\
Sukrosa & $2,0 \%$ & 10 & 10 & 10 \\
Asam sitrat & $0,1 \%$ & 0,5 & 0,5 & 0,5 \\
Gum arab & $0,1 \%$ & 0,5 & 0,5 & 0,5 \\
\hline
\end{tabular}

Pengujian Sifat Kimia, Fisik, Mikrobiologi, dan Organoleptik

Analisis yang dilakukan meliputi: (1) pengujian karakteristik DFA III dari umbi dahlia dan umbi chicory; (2) pengujian sifat kimia yoghurt kering meliputi: kadar air, kadar abu, kadar protein, kadar lemak, kadar karbohidrat, $\mathrm{pH}$ atau derajat keasaman, keasaman sebagai asam laktat, dan kadar kalsium (AOAC, 2005); (3) pengujian sifat fisik meliputi: rendemen produk, dan derajat putih (AOAC, 2005), pengamatan bentuk fisik menggunakan Scanning Electron Microscopy (Goldstein dkk., 1992); (4) pengujian mikrobiologi dengan viabilitas bakteri asam laktat (BSN,
2009); dan (5) pengujian organoleptik meliputi: aroma, tekstur, rasa, dan warna berdasarkan tingkat hedonik dengan skala 1 - 6 (Soekarto dan Hubeis, 1992).

\section{Pengolahan dan Analisis Data}

Semua data yang diperoleh ditampilkan dalam bentuk nilai rerata + standar deviasi (Mean \pm SD). Nilai rata-rata dan standar deviasi dihitung dengan menggunakan aplikasi program Microsoft Excel 2007 dan SPSS versi 15. Data hasil pengukuran parameter dianalisis dengan sidik ragam (ANOVA) pada selang kepercayaan 95\%, apabila terdapat keragaman dilanjutkan dengan uji jarak berganda Duncan.

\section{HASIL DAN PEMBAHASAN}

\section{Karakteristik Difructose Anhydride III}

Difructose Anhydride III komersial berasal dari umbi chicory yang sudah diproduksi oleh Nippon Beet Sugar Mfg. Co. Ltd. Obihiro Hokkaido Jepang. DFA III dari umbi dahlia diperoleh dari Pusat Penelitian Kimia Lembaga Ilmu Pengetahuan Indonesia. Tanaman dahlia tumbuh baik di daerah Cihideung dan Cihanjuang kawasan Lembang, Cibodas dan Cipanas kawasan Cianjur, dan Salabintana kawasan Sukabumi.

Proses pembuatannya dimulai dari tahapan pemanenan umbi dahlia pada umur 7-10 bulan dari penanaman. Menurut Widowati (2006) umbi dahlia mempunyai masa panen 210 hari dengan produksi umbi sebesar 28,5 ton.ha ${ }^{-1}$. Inulin yang terdapat di dalam umbi dahlia dapat terurai menjadi fruktosa oleh enzim inulinase yang terdapat di dalam umbi (Whitley, 1985). Oleh karena itu, umbi dahlia perlu segera diolah setelah dipanen, dengan cara diproses menjadi irisan tipis dan dikeringkan pada suhu $60^{\circ} \mathrm{C}$. Menurut Takeuchi dan Nagashima (2011), pemanasan pada suhu $60^{\circ} \mathrm{C}$ untuk menginaktifkan enzim inulinase. Irisan (chips) umbi dahlia yang sudah kering kemudian dihaluskan menjadi tepung yang akan digunakan sebagai bahan baku pembuatan DFA III (Pudjiraharti dan Asano, 2012). Selanjutnya dilakukan proses pembentukan DFA III dari tepung umbi dahlia menggunakan enzim inulinfruktotransferase (IFTase) dari Nonomuraea sp. (Pudjiraharti dkk., 2011).

DFA III merupakan produk turunan dari inulin umbi dahlia dan aman digunakan sebagai bahan pangan, berdasarkan hasil penelitian Anan'ina dkk. (2009) terhadap standardisasi ekstrak inulin dari umbi dahlia dan sifat fisiko kimianya, yaitu kemampuan mengikat air, aktivitas pada bagian permukaan, kemampuan pembentukan misel, dan daya larut. Hasil analisis karakteristik DFA III sebagai bahan pengayaan untuk yoghurt kering dapat dilihat pada Tabel 2. 
Tabel 2. Karakteristik DFA III dari umbi dahlia dan umbi chicory

\begin{tabular}{lll}
\hline \multicolumn{1}{c}{ Karakteristik } & $\begin{array}{l}\text { DFA III } \\
\text { (umbi dahlia) }\end{array}$ & $\begin{array}{l}\text { DFA III } \\
\text { (umbi chicory) }\end{array}$ \\
\hline $\begin{array}{l}\text { Derajat putih } \\
\text { pH }\end{array}$ & $55,14 \%$ & $94,59 \%$ \\
Kelarutan dalam air pada & 6,6 & 5,7 \\
suhu $25^{\circ} \mathrm{C}$ & $100 \%$ & $100 \%$ \\
$\begin{array}{l}\text { Kekentalan dalam air } \\
\left(5 \%, 10^{\circ} \mathrm{C}\right)\end{array}$ & $2,9 \mathrm{mPa} . \mathrm{s}$ & $2,8 \mathrm{mPa} . \mathrm{s}$ \\
Kadar air & $0,59 \%$ & $0,09 \%$ \\
Gula total & $77,77 \%$ & $76,29 \%$ \\
Kalsium & $4,58 \mathrm{mg} .100 \mathrm{~g}^{-1}$ & $6,13 \mathrm{mg} .100 \mathrm{~g}^{-1}$ \\
Logam berat $\mathrm{Pb}$ & Tidak terdeteksi & Tidak terdeteksi \\
Tingkat kemurnian & $96,0 \%$ & $99,9 \%$ \\
\hline
\end{tabular}

Derajat putih DFA III dari umbi dahlia lebih rendah dibandingkan DFA III dari umbi chicory. Hal ini terjadi karena DFA III dari umbi dahlia yang digunakan masih berwarna kecokelatan. Warna tersebut kemungkinan berasal dari komponen-komponen hasil oksidasi senyawa polifenol atau fenolik atau poliasetilin, di mana pada saat pengeringan terjadi perubahan warna pada irisan umbi dahlia yang tidak di-blanching menjadi kecokelatan. Menurut Takeuchi dan Nagashima (2011) bahwa proses browning pada irisan umbi selama pengeringan terjadi karena oksidasi senyawa fenolik oleh polifenoloksidase (PPO).

\section{Pengayaan Difructose Anhydride III pada Yoghurt Kering}

Hasil pengujian yoghurt segar yang digunakan dalam proses pembuatan yoghurt kering ini sesuai dengan Standar Nasional Indonesia untuk yoghurt segar dengan nomor 01.2981-2009 (BSN, 2009) sehingga memenuhi syarat untuk digunakan sebagai bahan dasar pembuatan yoghurt kering. Hasil analisis yoghurt segar dibandingkan dengan SNI disajikan pada Tabel 3.

Tabel 3. Hasil analisis yoghurt segar dibandingkan dengan SNI No. 01.2981-2009

\begin{tabular}{lcc}
\hline \multicolumn{1}{c}{ Parameter } & Yoghurt segar & $\begin{array}{c}\text { SNI } \\
\text { yoghurt segar *) }\end{array}$ \\
\hline pH/ derajat keasaman & 3,85 & - \\
Keasaman sebagai asam laktat & $0,50 \%$ & $0,5-2,0 \%$ \\
Viabilitas bakteri asam kaktat & $6,1 \times 10^{7}$ cfu.g $^{-1}$ & Min $10^{7} \mathrm{cfu}^{-1}$ \\
Kadar air & $92,24 \%$ & - \\
Kadar abu & $0,78 \%$ & Maks. $1,0 \%$ \\
Kadar protein (N x 6.38) & $2,80 \%$ & $2,70 \%$ \\
Kadar lemak & $0,97 \%$ & $0,50 \%$ \\
Kadar karbohidrat & $3,21 \%$ & - \\
\hline
\end{tabular}

*) Badan Standardisasi Nasional, 2009
Pengayaan DFA III pada pangan fungsional dipilih yoghurt, karena yoghurt mengandung kadar kalsium relatif lebih tinggi (0,179\%) dibandingkan susu segar. Menurut Tamime dan Robinson (2007) yoghurt mengandung kadar kalsium $(0,145 \%)$ dan susu segar $(0,119 \%)$. Hasil analisis kadar kalsium dari yoghurt segar dan yoghurt kering yang diperkaya DFA III disajikan pada Tabel 4.

Tabel 4. Kadar kalsium yoghurt segar dan yoghurt kering

\begin{tabular}{lcl}
\hline Jenis yoghurt & Kadar kalsium & Keterangan \\
\hline Yoghurt segar & $0,199 \%$ & $\begin{array}{l}\text { Weinsier dan } \\
\text { Krumdieck (2000) } \\
\text { Yoghurt segar }\end{array}$ \\
$\begin{array}{lcl}\text { Tamime dan Robinson } \\
(2007)\end{array}$ \\
$\begin{array}{l}\text { Yoghurt segar } \\
\text { Yoghurt segar }\end{array}$ & $0,160 \%$ & $\begin{array}{l}\text { Mazahreh dan } \\
\text { Ershidat(2009) }\end{array}$ \\
$\begin{array}{l}\text { Yoghurt kering tanpa } \\
\text { pengayaan }\end{array}$ & $0,179 \%$ & Herminiati dkk. (2014) \\
$\begin{array}{l}\text { Yoghurt kering } \\
\text { diperkaya DFA III dari } \\
\text { umbi dahlia }\end{array}$ & $0,334 \%$ & Herminiati dkk. (2014) \\
$\begin{array}{l}\text { Yoghurt kering } \\
\text { diperkaya DFA III dari }\end{array}$ & $0,322 \%$ & Herminiati dkk. (2014) \\
umbi chicory & & \\
\hline
\end{tabular}

Tahapan proses yang paling penting pada pembuatan yoghurt kering adalah pencampuran bahan-bahan penunjang ke dalam yoghurt segar, untuk homogenisasi larutan menggunakan homogenizer, selanjutnya di keringkan menggunakan spray dryer. Menurut Eddy (1999), spray dryer dapat digunakan untuk pengeringan yoghurt, hasil pengeringan menggunakan suhu inlet $120^{\circ} \mathrm{C}$ dan outlet $80^{\circ} \mathrm{C}$, setelah rehidrasi $10 \%$ memiliki aroma yang terbaik.

\section{Karakteristik Sifat Kimia, Fisik, dan Mikrobiologi Yoghurt Kering}

Hasil analisis kimia dari ketiga perlakuan yoghurt kering disajikan pada Tabel 5. Hasil penelitian menunjukkan bahwa kadar air yoghurt kering yang diperkaya DFA III dari umbi dahlia (YD) lebih tinggi secara nyata dibandingkan dengan yoghurt kering tanpa pengayaan (Y) dan yang diperkaya dengan DFA III komersial dari umbi chicory (YC). Kadar abu dari yoghurt kering tanpa pengayaan (Y) lebih tinggi secara nyata dibandingkan produk YD dan YC. Kadar abu pada produk yoghurt dipengaruhi oleh kandungan mineral di dalam produk, yang dapat berasal dari susu skim dan DFA III.

Analisis $\mathrm{pH}$ atau derajat keasaman berkisar antara $3,85 \pm 0,07-3,90 \pm 0,00$ menunjukkan tidak berbeda nyata, nilai ini sudah memenuhi $\mathrm{pH}$ yoghurt yang baik antara $\mathrm{pH}$ 
Tabel 5. Hasil analisis kimia yoghurt kering dengan 3 perlakuan

\begin{tabular}{lccrr}
\hline \multicolumn{1}{c}{ Parameter } & & Tanpa pengayaan (Y) & $\begin{array}{c}\text { Diperkaya DFA III umbi dahlia } \\
\text { (YD) }\end{array}$ & $\begin{array}{l}\text { Diperkaya DFA III umbi } \\
\text { chicory (YC) }\end{array}$ \\
\hline Air & $(\%)$ & $7,32 \pm 0,16^{\mathrm{a}}$ & $7,89 \pm 0,01^{\mathrm{b}}$ & $7,29 \pm 0,18^{\mathrm{a}}$ \\
Abu & $(\%)$ & $4,42 \pm 0,09^{\mathrm{b}}$ & $3,43 \pm 0,06^{\mathrm{a}}$ & $3,25 \pm 0,07^{\mathrm{a}}$ \\
Protein & $(\%)$ & $13,24 \pm 0,15^{\mathrm{b}}$ & $12,43 \pm 0,13^{\mathrm{a}}$ & $12,48 \pm 0,26^{\mathrm{a}}$ \\
Lemak & $(\%)$ & $1,58 \pm 0,42^{\mathrm{a}}$ & $1,22 \pm 0,07^{\mathrm{a}}$ & $0,98 \pm 0,05^{\mathrm{a}}$ \\
Karbohidrat & $(\%)$ & $63,44 \pm 0,64^{\mathrm{a}}$ & $75,02 \pm 0,10^{\mathrm{b}}$ & $76,00 \pm 0,55^{\mathrm{b}}$ \\
pH atau derajat keasaman & & $3,90 \pm 0,00^{\mathrm{a}}$ & $3,90 \pm 0,00^{\mathrm{a}}$ & $3,85 \pm 0,07^{\mathrm{a}}$ \\
Keasaman (asam laktat) & $(\%)$ & $0,63 \pm 0,00^{\mathrm{b}}$ & $0,49 \pm 0,02^{\mathrm{a}}$ & $0,45 \pm 0,04^{\mathrm{a}}$ \\
\hline
\end{tabular}

Keterangan : huruf yang sama pada baris yang sama, menunjukkan tidak ada perbedaan pada uji lanjut Duncan dengan tingkat kepercayaan $95 \%$ ( $<0,05$ )

3,8 - 4,6 (Tamime dan Robinson, 2007), selanjutnya menurut Chandan dkk. (2006) pH minuman yoghurt segar bervariasi antara 4,0 - 4,5. Nilai $\mathrm{pH}$ yang rendah pada produk yoghurt terbentuk karena adanya asam laktat sebagai hasil degradasi laktosa oleh bakteri asam laktat. Keasaman sebagai asam laktat pada produk Y lebih tinggi secara nyata dibandingkan produk YD dan YC, hal ini dipengaruhi oleh pengayaan DFA III sebagai prebiotik.

Kadar protein pada yoghurt kering dipengaruhi oleh penambahan susu skim. Kadar karbohidrat pada produk YD dan YC lebih tinggi secara nyata dibandingkan dengan produk Y, karena pada produk YD dan YC selain ditambahkan pati jagung sebagai sumber karbohidrat juga ditambahkan DFA III. Kadar lemak pada produk Y tidak berbeda secara nyata dibandingkan dengan produk YD dan YC.

Hasil analisis fisik meliputi rendemen produk dan derajat putih dapat dilihat pada Tabel 6, dan bentuk yoghurt kering dari hasil pengamatan Scanning Electron Microscopy
(SEM) dengan pembesaran 1000x dapat dilihat pada Gambar 1.

Hasil penelitian menunjukkan bahwa rendemen yoghurt kering yang diperkaya DFA III dari umbi dahlia lebih tinggi secara nyata, dibandingkan dengan yoghurt tanpa pengayaan (Y), dan yang diperkaya dengan DFA III komersial dari umbi chicory (YC). Pengayaan DFA III komersial dari umbi chicory memberikan hasil yang lebih rendah, karena produk yoghurt kering sebagian menempel pada kolom spray dryer pada saat proses pengeringan berlangsung.

Derajat putih dari produk $\mathrm{Y}$ lebih tinggi secara nyata dibandingkan dengan produk YD dan YC. Hal ini menunjukkan pengayaan DFA III dapat mempengaruhi warna produk, karena pada saat pemanasan tinggi menggunakan spray dryer terbentuk karamel dari DFA III yang menimbulkan warna agak kecokelatan.

Pengujian dengan SEM dilakukan untuk menentukan morfologi permukaan dan ukuran kapsul serta gambar

Tabel 6. Hasil analisis rendemen produk dan derajat putih yoghurt kering dengan 3 perlakuan

\begin{tabular}{|c|c|c|c|}
\hline Parameter & Tanpa pengayaan $(\mathrm{Y})$ & $\begin{array}{c}\text { Diperkaya DFA III umbi dahlia } \\
\text { (YD) }\end{array}$ & $\begin{array}{c}\text { Diperkaya DFA III umbi } \\
\text { chicory }(\mathrm{YC})\end{array}$ \\
\hline Rendemen produk (\%) & $14,90 \pm 1,27^{\mathrm{a}}$ & $17,83 \pm 0,36^{\mathrm{b}}$ & $14,71 \pm 1,69^{\mathrm{a}}$ \\
\hline Derajat putih $\quad(\%)$ & $92,27 \pm 0,11^{\mathrm{c}}$ & $89,29 \pm 0,08^{b}$ & $86,66 \pm 0,08^{\mathrm{a}}$ \\
\hline
\end{tabular}

Keterangan : huruf yang sama pada baris yang sama, menunjukkan tidak ada perbedaan pada uji lanjut Duncan dengan tingkat kepercayaan $95 \%$ (p $<0,05$ )

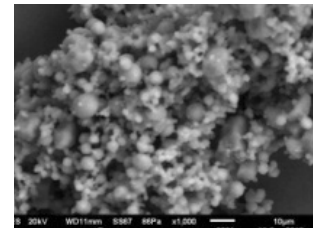

Tanpa pengayaan

(Y)

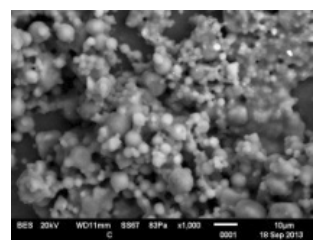

Diperkaya DFA III umbi dahlia

(YD)

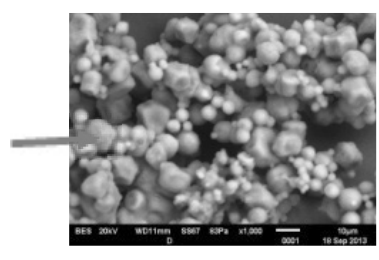

Diperkaya DFA III umbi chicory

(YC)

Keterangan : tanda panah menunjukkan DFA III dari umbi chicory

Gambar 1. Hasil pengamatan scanning electron microscopy yoghurt kering 
permukaan spesimen. Bentuk fisik produk YC terlihat lebih merata dan partikel memiliki bentuk bola dan kubus dengan permukaan yang halus dibandingkan dengan produk Y dan YD. Hal ini dipengaruhi oleh pengayaan DFA III dari umbi chicory yang memiliki tingkat kemurnian 99,9\%, sedangkan DFA III dari umbi dahlia 96,0\%. Pada produk YC terlihat bentuk kristal DFA III, walaupun telah melewati proses pemanasan dengan menggunakan spray dryer masih bisa terlihat kompak dan stabil.

Bentuk fisik yang tidak merata dengan permukaan yang padat pada produk Y dan YD, disebabkan penggunaan panas pada proses spray drying. Menurut Deladino dkk. (2008), suhu pemanasan pada proses pengeringan dapat mengakibatkan kehilangan senyawa aktif sehingga permukaan menjadi lebih padat.

Pada Tabel 7 disajikan hasil analisis mikrobiologi terhadap viabilitas bakteri asam laktat yang terdapat pada yoghurt kering dengan tiga perlakuan. Viabilitas bakteri asam laktat pada ketiga produk yoghurt kering masih memenuhi

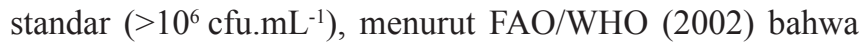
probiotik adalah mikroorganisme hidup yang masuk dalam jumlah yang cukup $\left(10^{6}-10^{8}\right.$ cfu.mL $\left.\mathrm{m}^{-1}\right)$ sehingga dapat memberikan manfaat kesehatan bagi inangnya. Hal ini dipengaruhi oleh adanya penambahan $10 \%$ pati jagung sebagai bahan pengisi ke dalam yoghurt dan DFA III yang bersifat prebiotik, sebelum proses pengeringan dilakukan. Berdasarkan hasil penelitian Eddy (1999) bahwa yoghurt kering yang sebelumnya ditambahkan $10 \%$ pati, setelah rehidrasi dapat memberikan rasa yang lebih baik dan total bakteri asam laktat tertinggi.

Tabel 7. Viabilitas bakteri asam laktat yoghurt kering dengan 3 perlakuan

\begin{tabular}{cccc}
\hline $\begin{array}{c}\text { Viabilitas bakteri } \\
\text { asam laktat }\left(\text { cfu.g }{ }^{-1}\right)\end{array}$ & $\begin{array}{c}\text { Tanpa } \\
\text { pengayaan } \\
(\mathrm{Y})\end{array}$ & $\begin{array}{l}\text { Diperkaya } \\
\text { DFA III umbi } \\
\text { dahlia (YD) }\end{array}$ & $\begin{array}{l}\text { Diperkaya DFA } \\
\text { III umbi chicory } \\
(\mathrm{YC})\end{array}$ \\
\hline $\mathrm{T}=20^{\circ} \mathrm{C}, \mathrm{t}=0$ hari & $1,61 \times 10^{6}$ & $1,20 \times 10^{7}$ & $7,50 \times 10^{6}$ \\
$\mathrm{~T}=20^{\circ} \mathrm{C}, \mathrm{t}=15$ hari & $1,56 \times 10^{6}$ & $2,60 \times 10^{6}$ & $2,80 \times 10^{6}$ \\
$\mathrm{~T}=20^{\circ} \mathrm{C}, \mathrm{t}=30$ hari & $9,50 \times 10^{4}$ & $1,90 \times 10^{6}$ & $2,20 \times 10^{6}$ \\
\hline
\end{tabular}

Pada awal penyimpanan dengan suhu $20^{\circ} \mathrm{C}$ menggunakan pengemas aluminum foil, viabilitas bakteri asam laktat dari yoghurt kering yang diperkaya DFA III dari umbi dahlia (YD) memberikan hasil yang lebih tinggi. Hal ini menunjukkan bahwa pengayaan dengan DFA III yang bersifat prebiotik mampu meningkatkan substrat yang dapat digunakan oleh bakteri asam laktat (BAL) sebagai probiotik sehingga mempunyai kemampuan untuk hidup lebih lama. Hasil penelitian Ngatirah dan Ulfah (2013) dengan penambahan tepung sumber prebiotik dari umbi dahlia untuk enkapsulasi probiotik dapat meningkatkan jumlah sel sampai
1 silkus log, karena senyawa prebiotik dari umbi dahlia dapat masuk ke dalam matriks kapsul serta menutupi pori-pori kapsul sehingga dapat menahan laju difusi asam.

Viabilitas bakteri asam laktat dari produk YD dan YC relatif lebih tinggi dibandingkan produk $\mathrm{Y}$, hal ini dipengaruhi oleh pengayaan DFA III yang berasal dari umbi dahlia dan umbi chicory. Produk Y masih memiliki viabilitas bakteri asam laktat $\left(10^{6} \mathrm{cfu}^{-\mathrm{g}^{-1}}\right)$ sesuai standar. Hal ini terjadi, karena proses pembuatan yoghurt kering dengan menggunakan spray dryer pada suhu inlet $120^{\circ} \mathrm{C}$ dan outlet $80^{\circ} \mathrm{C}$, dengan penambahan pati jagung dan DFA III sebagai senyawa prebiotik dapat melindungi probiotik dengan cara enkapsulasi, sehingga dapat mempertahankan viabilitas bakteri asam laktat. And dan Kailasapathy (2005) menjelaskan bahwa penambahan pati Hi-Maize dengan konsentrasi $1 \%$ (b/v) pada proses enkapsulasi mampu melindungi sel terhadap pengaruh pH 2,0 dan mampu meningkatkan jumlah sel secara nyata, karena pati Hi-Maize mampu masuk ke dalam matriks kapsul dan menutupi pori-pori kapsul sehingga mencegah terjadinya difusi asam ke dalam kapsul.

Setelah penyimpanan hari ke-30 produk YD dan YC masih menunjukkan viabilitas bakteri asam laktat yang stabil $\left(10^{6}\right.$ cfu. $\left.^{-1}\right)$, sedangkan produk Y berada pada batas mutu produk yang diharapkan dengan viabilitas bakteri asam laktat $\left(<10^{6}\right)$, menunjukkan nilai mutu produk yang mulai ditolak konsumen. Hasil penelitian Allgeyer dkk. (2010) yang menambahkan 3 jenis prebiotik pada yoghurt (polydextrose, inulin chicory, dan serat jagung larut), setelah 10 hari penyimpanan pada suhu dingin, viabilitas probiotik menurun sekitar $70 \%$ pada perlakuan penambahan prebiotik polydextrose dan serat jagung larut, tetapi yoghurt yang diberi perlakuan penambahan prebiotik inulin chicory viabilitas bakteri asam laktat dapat bertahan dengan tingkat kelangsungan hidup yang tinggi.

Roberfroid (2007) menyatakan bahwa inulin sebagai prebiotik dapat menghasilkan short chain fatty acids (SCFA) yang meliputi propionat, butirat, asetat, dan laktat. Asam laktat dapat membuat $\mathrm{pH}$ usus menjadi asam, kondisi ini menyebabkan ion kalsium menjadi lebih mudah larut, sehingga meningkatkan penyerapan kalsium pada usus besar. Selanjutnya Donkor dkk. (2007) menjelaskan bahwa yoghurt yang mengandung probiotik dengan ditambahkan prebiotik dapat meningkatkan konsentrasi asam asetat dan asam laktat, dimana keberadaan asam laktat dan asam lemak rantai pendek di dalam usus besar mampu meningkatkan penyerapan kalsium. Dengan demikian yoghurt kering yang diperkaya DFA III selain bersifat prebiotik juga masih mengandung probiotik yang tinggi, sehingga masuk kriteria sebagai minuman sinbiotik.

Produk yoghurt kering Y, YD, dan YC dapat digolongkan sebagai minuman fungsional. Menurut FAO (2004) pangan 
fungsional mengandung komponen biologis aktif yang terdapat secara alami atau ditambahkan dan mempunyai manfaat fisiologis bagi kesehatan. Senada dengan hasil penelitian Allgeyer dkk. (2010) bahwa produk susu yang diperkaya dengan prebiotik dan probiotik perkembangannya pesat dan meningkat, karena konsumen lebih menyukai makanan yang beraroma dan menunjang kesehatan.

Sinbiotik didefinisikan sebagai suatu kombinasi dari prebiotik dan probiotik yang menguntungkan inang, dengan meningkatkan pertahanan dan implantasi suplemen makanan yang mengandung mikrobia hidup dalam saluran pencernaan, yang secara selektif memicu pertumbuhan dan atau mengaktifkan metabolisme dari sejumlah bakteri baik sehingga meningkatkan kesehatan inangnya (Panesar dkk., 2009). Kombinasi ini dapat meningkatkan tingkat kelangsungan hidup probiotik dan memberikan manfaat kesehatan tambahan untuk host (Collins dan Gibson, 1999). Manfaat mengonsumsi pangan sinbiotik di antaranya dapat meningkatkan penyerapan mineral dan kalsium sehingga dapat mencegah osteoporosis (Bosscher dkk., 2006).

\section{Karakteristik Organoleptik Yoghurt Kering}

Pengujian organoleptik meliputi: aroma, tekstur, rasa, dan warna menggunakan metode Soekarto dan Hubeis (1992) oleh 40 panelis semi terlatih. Skala hedonik yang dijadikan penilaian : $1=$ tidak suka, $2=$ kurang suka, $3=$ agak suka, $4=$ suka, 5 = sangat suka, dan $6=$ amat sangat suka. Hasil pengujian organoleptik disajikan pada Gambar 2.

Hasil penilaian untuk aroma dan rasa lebih tinggi secara nyata pada yoghurt yang diperkaya DFA III dari umbi chicory (YC), sedangkan untuk tekstur dan warna menunjukkan hasil tidak berbeda secara nyata dari ke tiga produk tersebut.

Aroma pada yoghurt kering yang diperkaya DFA III (produk YD dan YC) lebih disukai dibandingkan produk Y, sedangkan DFA III tidak memiliki aroma. Hal ini terjadi karena pada saat pemanasan tinggi menggunakan spray dryer menimbulkan aroma wangi karamel, yang mengakibatkan aroma produk lebih disukai oleh panelis. Penilaian terhadap rasa pada yoghurt kering yang diperkaya DFA III dari umbi chicory (YC) agak disukai dibandingkan dengan produk Y dan YD, karena DFA III memiliki rasa manis separuh kemanisan sukrosa (Asano, 2005), akibatnya setelah proses spray drying produk yoghurt kering terasa sedikit lebih manis. DFA III juga memiliki titik leleh yang tinggi $\left(162^{\circ} \mathrm{C}\right)$ dan tidak akan membentuk karamel pada proses spray drying (Kikuchi dkk., 2004), karena karamelisasi yang berlebih dapat menyebabkan rasa pahit.

Pengayaan DFA III tidak mempengaruhi tekstur yoghurt kering, karena DFA III adalah senyawa yang sangat mudah larut dalam air dan pada saat dicampurkan ke dalam yoghurt

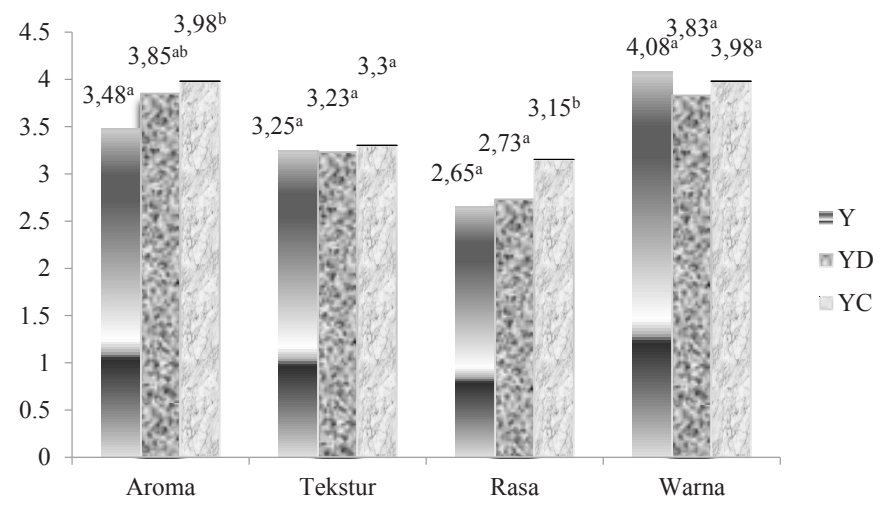

Keterangan : $\mathrm{Y}=$ Yoghurt kering tanpa pengayaan

$\mathrm{YD}=$ Yoghurt kering diperkaya dengan DFA III dari umbi dahlia

$\mathrm{YC}=$ Yoghurt kering diperkaya dengan DFA III dari umbi chicory

Gambar 2. Hasil pengujian organoleptik terhadap aroma, tekstur, rasa, dan warna.

segar larut sempurna membentuk campuran yang homogen, sehingga setelah proses spray drying tidak mengubah tekstur produk yoghurt kering. Hal ini sesuai dengan hasil penelitian Anan'ina dkk. (2009) bahwa ekstrak inulin dari umbi dahlia sebagai bahan baku DFA III memiliki kemampuan mengikat air dengan daya larut tinggi. Penilaian panelis menunjukkan tidak berbeda nyata pada warna yoghurt kering yang disajikan dengan cara melarutkan 10 gram yoghurt kering ke dalam $100 \mathrm{ml}$ air.

\section{KESIMPULAN}

Karakteristik yoghurt kering yang diperkaya dengan DFA III dari umbi dahlia dan umbi chicory yang bersifat prebiotik dapat mempertahankan viabilitas bakteri asam laktat sebagai probiotik sampai penyimpanan hari ke-30 pada suhu $20^{\circ} \mathrm{C}$ dengan menggunakan pengemas aluminum foil, yang membuktikan bahwa produk yoghurt kering tersebut dapat digolongkan sebagai produk sinbiotik. DFA III dari umbi dahlia sebagai produk lokal dapat menggantikan DFA III dari umbi chicory yang merupakan produk impor, berdasarkan aplikasinya pada minuman fungsional yoghurt kering terhadap karakteristik sifat kimia, fisik, mikrobiologi, dan organoleptik.

\section{UCAPAN TERIMA KASIH}

Terima kasih kepada Deputi Bidang Sumber Daya Iptek Kementerian Riset dan Teknologi, Badan Penelitian dan Pengembangan Pertanian Kementerian Pertanian yang telah mendanai penelitian ini. 


\section{DAFTAR PUSTAKA}

Allgeyer, L.C., Miller, M.J. dan Lee, S.Y. (2010). Sensory and microbiological quality of yogurt drinks with prebiotics and probiotics. Journal of Dairy Science 93(10): 44714479.

Anan'ina, N.A., Andreeva, O.A., Mycots, L.P. dan Oganesyan, E.T. (2009). Standardization of inulin extracted from dahlia single tubers and some physicochemical properties of inulin. Pharmaceutical Chemistry Journal 43(3): 157-160.

And, C.I. dan Kailasapathy K. (2005). Effect of coencapsulation of probiotics with prebiotics on increasing the viability of encapsulated bacteria under in vitro acidic and bile salt conditions and in yoghurt. Journal of Food Science 70(1): M18-M23.

[AOAC] Association of Official Analytical Chemists (2005). Official Methods of Analysis of Association of Official Analytical Chemists. Association of Official Analitycal Chemists. Washington DC.

Asano, K. (2005). Oligosaccharides function to promote calcium absorption and prevent osteoporosis. Functional foods: trends and challenges. LIPI Press 1: 11-32.

Bosscher, D., Van Loo, J. dan Franck, A. (2006). Inulin and oligofructose: as functional ingredients to improve bone mineralization. International Dairy Journal 16: 10921097.

[BSN] Badan Standardisasi Nasional (2009). SNI No. 01.2981-2009. Syarat Mutu Yoghurt. Badan Standardisasi Nasional, Jakarta.

Chandan, R.C., White, C.H., Kilara, A. dan Hui, Y.H. (2006). Manufacturing Yogurt and Fermented Milks. Blackwell Publishing, Ames, IA.

Collins, M.D. dan Gibson, G.R. (1999). Probiotics, prebiotics, and synbiotics: approaches for modulating the microbial ecology of the gut. American Journal Clinical Nutrition 69: $1052 \mathrm{~S}-1057 \mathrm{~S}$.

Deladino, L., Anbinder, P.S., Navarro, A.S. dan Martino, M.N. (2008). Encapsulation of natural antioxidants extracted from Ilex paraguariensis. Carbohydrate Polymers 71: 126-134.

Donkor, O.N., Nilmini, S.L.I., Stolic, P., Vasiljevic, T. dan Shah, N.P. (2007). Survival and activity of selected probiotic organisms in set type yogurt during cold storage. International Dairy Journal 17: 657-665.
Eddy, F.F. (1999). Pembuatan Yoghurt Kering dengan Menggunakan Pengering Semprot. Skripsi. Fakultas Teknologi Pertanian. Institut Pertanian Bogor, Bogor.

[FAO/WHO]. (2002). Guidelines for The Evaluation of Probiotics in Food. Report of join FAO/WHO Working Group on drafting guidelines for the evaluation of probiotics in food. London Ontario, Canada.

[FAO]. (2004). Report of the regional consultation of the Asia-Pacific network for food and nutrition on functional foods and their implications in the daily diet. RAP Publication 33: 61.

Goldstein, J.I., Newbury, D.E., Echlin, P., Joy, D.C., Romig, A.D., Lyman, C.E., Fiori, C. dan Lifshin, E. (1992). Scanning Electron Microscopy and X-Ray Microanalysis, $2^{\text {nd }}$ Edn. Plenum Press, New York (AS).

Hardcastle, A.C., Aucott, L., Fraser, W.D., Reid, D.M. dan Macdonald, H.M. (2011). Dietary patterns, bone resorption and bone mineral density in early postmenopausal Scottish women. European Journal of Clinical Nutrition 65: 378-385.

Herminiati, A., Rimbawan, Setiawan, B., Astuti, D.A. dan Zalinar, L. (2014). Efektivitas Difructose Anhydride III untuk meningkatkan penyerapan kalsium pada tulang femur tikus model defisien kalsium. Makalah disampaikan pada Seminar Sekolah Pascasarjana Institut Pertanian Bogor, 28 April 2014. Bogor.

Jenie, B.S.L. (2003). Pangan fungsional penyusun flora usus yang menguntungkan. Makalah disajikan dalam seminar sehari Keseimbangan Flora Usus bagi Kesehatan dan Kebugaran, 15 Februari 2003. Bogor.

Kikuchi, H., Nagura, T., Inoue, M., Kishida, T., Sakurai, H., Yokota, A., Asano, K., Tomita, F., Sayama, K.dan Senba, Y. (2004). Physical, chemical and physiological properties of Difructose Anhydride III produced from inulin by enzymatic reaction. Journal of Applied Glycoscience 51(4): 291-296.

Kikuchi, H., Inoue, M., Saito, H., Sakurai, H., Aritsuka, T., Tomita, F. dan Yokota, A. (2009). Industrial production of Difructose Anhydride III from crude inulin extracted from chicory roots using Arthrobacter sp. H657 fructosyl-transferase. Journal of Bioscience and Bioengineering 107(3): 262-265.

Lestari, N.P.A. (2011). Formulasi Yoghurt Sinbiotik dengan Penambahan Puree Pisang dan Inulin. [Skripsi]. Fakultas Teknologi Pertanian. Institut Pertanian Bogor, Bogor. 
Mazahreh, A.S. dan Ershidat, O.T.M. (2009). The benefits of lactic acid bacteria in yogurt on the gastrointestinal function and health. Pakistan Journal of Nutrition 8(9): 1404-1410.

Minamida, K., Asakawa, C., Nengah, S.I., Maki, K., Ayumi, A., Sone, T., Hara, H., Asano, K. dan Tomita, F. (2006). Effects of long-term ingestion of Difructose Anhydride III on intestinal bacteria and bile acid metabolism in humans. Journal of Bioscience and Bioengineering 101(2): 149-155.

Mitamura, R., Hiroshi, H., Yoritaka, A. dan Chiji, H. (2002). Supplemental feeding of Difructose Anhydride III restores calcium absorption impaired by ovariectomy in rats. Journal of Nutrition 132: 3387-3393.

Ngatirah dan Ulfah, M. (2013). Penambahan tepung umbi dahlia, kedelai, dan bawang putih sebagai sumber prebiotik untuk enkapsulasi probiotik. Jurnal Teknologi dan Industri Pangan 24(1): 14-21.

Panesar, P.S., Kaur, G., Panesar, R. dan Bera, M.B. (2009). Synbiotics: potential dietary supplements in functional foods. FST Bulletin, Food Science Central, IFIS Publishing UK. http://www.foodsciencecentral.com/ fsc/ixid15649. [10 agustus 2011].

Pudjiraharti, S., Takesue, N., Katayama, T., Lisdiyanti, P., Hanafi, M., Tanaka, M., Sone, T.dan Asano, K. (2011). Actinomycete Nonomuraea sp. isolated from Indonesian soil is a new producer of inulin fructotransferase. Journal of Bioscience and Bioengineering 20(20): 1-4.

Pudjiraharti, K. dan Asano, K. (2012). Proses pembuatan Difructose Anhydride III dari umbi dahlia menggunakan enzim inulin fruktotransferase dari Nonomurae sp ID06-A0189. Paten terdaftar No. Paten P00201200458.

Roberfroid, M.B. (2007). Inulin and oligofructose: health benefits and claims-a critical review. Journal of Nutrition 137: 2493S-2502S.

Saint-Eve, A., Levy, C., Martin, N., dan Souchon, I. (2006). Influence of proteins on the perception of flavored stirred yogurts. Journal of Dairy Science 89: 922-933.
Sato, T., Nakai, T., Sadoya, H., Ohtami, M., Hanada, M. dan Okamoto, M. (2007). Effect of Difructose Anhydride III on hypocalcemia in dairy cows after calving. Animal Science Journal 78(1): 37-43.

Shigematsu, N., Okuhara, Y., Shiomi, T., Tomita, F. dan Hara, H. (2004). Effect of Difructose Anhydride III on calcium absorption in humans. Bioscience, Biotechnology, and Biochemistry 68(5): 1011-1016.

Soekarto, S.T. dan Hubeis, M. (1992). Metodologi Penelitian Organoleptik. Pusat Antar Universitas Pangan dan Gizi. Institut Pertanian Bogor, Bogor.

Suzuki, T., Hara, H., Kasai, T. dan Tomita, F. (1998). Effects of Difructose Anhydride III on calcium absorption in small and large intestines of rats. Bioscience, Biotechnology, and Biochemistry 62(5): 837-841.

Suzuki, T. dan Hara, H. (2004). Various non-digestible saccharides increase intracellular calcium ion concentration in rat small-intestinal enterocytes. British Journal of Nutrition 92: 751-755.

Takeuchi, J. dan Nagashima, T. (2011). Preparation of dried chips from Jerusalem artichoke (Helianthus tuberosus L.) tubers and analysis of their functional properties. Food Chemistry 126: 922-926.

Tamime, A.Y. dan Robinson, R.K. (2007). Yoghurt Science and Technology, $3^{\text {rd }}$ edn. CRC Press, Cambridge, England.

Whitley, G.R. (1985). The medicinal and nutritional properties of Dahlia spp. Journal of Ethnopharmacology 14: 7582.

Widowati, S. (2006). Dahlia Bunganya Indah, Umbinya Mengandung Inulin. Sinar Tani edisi 19-25 April 2006.

Weinsier, R. dan Krumdieck, C. (2000). Dairy foods and bone health: examination of the evidence. American Journal of Clinical Nutrition 72(3): 681-689. 